\title{
Novel Polymorphisms in RAPGEF6 Gene Associated with Egg-Laying Rate in Chinese Jing Hong Chicken using Genome-Wide SNP Scan
}

\author{
Syed Ali Azmal ${ }^{1,2}$, Ali Akbar Bhuiyan ${ }^{1,3}$, Abdullah Ibne Omar ${ }^{1}$, Shuai Ma ${ }^{1}$, Chenghao Sun ${ }^{4}$, \\ Zhongdong Han ${ }^{4}$, Meikuen Zhang ${ }^{5}$, Shuhong Zhao ${ }^{1}$ and Shijun Li ${ }^{1, *}$ \\ 1 Key Laboratory of Agricultural Animal Genetics, Breeding and Reproduction, Ministry of Education, \\ College of Animal Science and Veterinary Medicine, Huazhong Agricultural University, \\ Wuhan 430070, China; azmal@webmail.hzau.edu.cn (S.A.A.); aab@blri.gov.bd (A.A.B.); \\ abdullah.ohi2014@webmail.hzau.edu.cn (A.I.O.); koma456@163.com (S.M.); shzhao@mail.hzau.edu.cn (S.Z.) \\ 2 Department of Livestock Services (DLS), Under the Ministry of Fisheries and Livestock (MOFL), \\ Dhaka 1000, Bangladesh \\ 3 Biotechnology Division, Bangladesh Livestock Research Institute, Under the Ministry of Fisheries and \\ Livestock (MOFL), Dhaka 1000, Bangladesh \\ 4 Huadu Yukou Poultry Industry Co. Ltd., Beijing 100000, China; chenghaosun567@gmail.com (C.S.); \\ zhongdonghan82@gmail.com (Z.H.) \\ 5 DQY Ecological Co. Ltd., Beijing 100000, China; meikuenzhang@gmail.com \\ * Correspondence: lishijun@mail.hzau.edu.cn; Tel.: +86-27-87281306; Fax: +86-27-87280408
}

Received: 4 April 2019; Accepted: 14 May 2019; Published: 20 May 2019

\begin{abstract}
The improvement of egg production is of vital importance in the chicken industry to maintain optimum output throughout the laying period. Because of the elongation of the egg-laying cycle, a drop in egg-laying rates in the late laying period has provoked great concern in the poultry industry. In this study, we calculated the egg-laying rate at weeks 61-69 (60 days) of Jing Hong chickens parent generation as the phenotype, and the genotype were detected by the chicken 600K Affymetrix Axiom High Density (HD) Single Nucleotide Polymorphisms (SNP)-array. The Genome-Wide Association Study (GWAS) result showed that the egg production trait is significantly associated with five SNPs (AX-75745366, AX-75745380, AX-75745340, AX-75745388, and AX-75745341), which are in the rap guanine nucleotide exchange factor 6 (RAPGEF6) gene on chicken chromosome 13. A total of 1676 Chinese commercial Jing Hong laying hens-including two populations, P1 population (858 hens) and P2 population ( 818 hens) - were genotyped using the Polymerase Chain Reaction-Restriction Fragments Length Polymorphisms (PCR-RFLP) method for the association analysis of egg-laying rates for the verification of the GWAS results. Genotypic and allelic frequencies of five SNPs were inconsistent with Hardy-Weinberg equilibrium, and the average population genetics parameters considering all the SNP values; i.e., gene homozygosity $(\mathrm{Ho})$, gene heterozygosity $(\mathrm{He})$, the effective number of alleles (Ne), and the polymorphism information content (PIC) were $0.75,0.25,1.40$, and 0.20 in P1; 0.71, 0.29, 1.46, and 0.24 in P2; and 0.73, 0.27, 1.43, and 0.22 in P1 + P2 populations, respectively. The association analysis results revealed that out of the five polymorphisms, three of them (AX-75745366, AX-75745340, and AX-75745341; Patent applying No: 201810428916.5) had highly significant effects on egg-laying rates according to the GWAS results. Population-specific association analyses also showed similar significant association effects with this trait. Four haplotypes (AAGG, AAAG, AGGG, and AGAG) were inferred based on significant loci (AX-75745340 and AX-75745341) and also showed significant associations with the egg-laying rate, where haplotype AAGG had the highest egg-laying rate, with the exception of the egg-laying rate in P1 population, followed by other haplotypes. Furthermore, genotypes TT, AA, and GG showed the highest egg-laying rate compared to the corresponding genotypes at AX-75745366, AX-75745340, and AX-75745341 SNP loci in P1+P2, respectively. A similar result was found in the population-specific analysis except for the P1 population,
\end{abstract}


in which TC genotype showed the highest egg-laying rate. No significant association was found in the egg-laying rate during the 60 days laying period for the SNPs (AX-75745380 and AX-75745388) in any group of population $(p \geq 0.05)$. Collectively, we report for the first time that 3 SNPs in the RAPGEF6 gene were significantly associated with the egg-laying rate during the later stage of egg production, which could be used as the potential candidate molecular genetic markers that would be able to facilitate in the selection and improvement of egg production traits through chicken breeding.

Keywords: Jing Hong chicken; egg-laying rate; GWAS; SNPs; RAPGEF6; association

\section{Introduction}

Chicken eggs are rich in protein, fatty acids, vitamins, and minerals, and are measured as an excellent source of animal protein. With the enhancement of laying hens' production performance, the laying age of commercial laying hens has been prolonged from the first $72-80$ weeks, and some breeding companies have even-continued the laying cycle to 100 weeks, recommending the breeding program "breeding for 500 eggs in 100 weeks" [1-3]. However, the rapid drop in egg-laying rates at the end of the laying cycle has severely hindered the attainment of this goal. Therefore, improving the egg-laying rate plays a vital role in realizing this program and extending the laying cycle. Improvement of egg production is a matter of concern in the poultry industry to enable egg producers to meet the enormous global demand. It is essential to maintain the optimum level of production throughout the laying period to make poultry farming profitable by minimizing the cost of production [4-6]. Published reports suggest that some birds in a layer flock should target the level of egg production at even the later stage of the rearing period; however, some laying hens have failed to achieve the expected production performance. Under such circumstances, the selection of layer birds showing a better egg production performance at a later stage may make layer farming significantly more profitable. During the late period of production, some laying chickens lay eggs at a productivity rate of $95 \%$ of maximum productivity, whereas some laying chicken lays eggs less at a productivity rate of than $80 \%$, which why the selection of higher egg-producing hens by breeding can make more benefit. The egg-laying performance in a particular layer flock fluctuates over time and can be represented in terms of a "production curve". The nature of the curvature is demarcated by subsequent stages, such as (a) sexual development (which results from the onset of production), followed by the highest production or (b) maximum egg production, followed by a slow decline in egg production or (c) continuation of egg production. Traditional breeding strategies designed to improve the efficiency of chicken egg production are based on a long term monitoring of egg numbers and laying rates; however, such techniques are always time-consuming [7]. During peak production, hen-day egg production in modern layers almost reaches its highest biological potential, attaining $96.98 \%$ of production (i.e., one egg per layer everyday); resulting in barely any dissimilarities in egg production performance among birds at this stage. Whatever fluctuates among layers is how extended they can continue a high rate of lay and at what rate production decreases after the peak [8-10]. Continuing a persistency of laying in the late period may have a positive impact on a flock's financial performance. An inherently augmented persistency in egg production of commercial layer enhances its performance to keep flocks at a more extended period of production.

A good number of previous investigations have been identified several polymorphisms in different genes of laying chicken that are closely associated with egg production traits including egg number, laying rate, egg weight, and egg quality characteristics [5,6,9-20]. The identification of a quantitative trait locus (QTL) controlling chicken reproductive performances for solicitation in marker-assisted selection (MAS) has been progressing quickly [21,22]. Reproduction traits are controlled by QTL, and a genome-wide scan is a practical approach that can be used to gain an understanding of these complex traits. As a statistical tool, a Genome-Wide Association Study (GWAS) is one of the most effective 
methods for identifying essential Single Nucleotide Polymorphisms (SNPs) and functional genes that affect quantitative traits [23]. The technique is more efficient at identifying genetic characteristics for economic traits than the candidate gene approach. In the present study, a GWAS was performed on 120 Jing Hong chickens of parent generations for 60 days at 61-69 weeks of age to observe egg production performance as the phenotype. Further, the genotype was detected by the chicken $600 \mathrm{~K}$ Affymetrix Axiom HD SNP-array to identify molecular markers and candidate genes associated with the egg-laying rate. The results found that five SNPs in chromosome 13 were significantly associated with the egg-laying rate. However, the GWAS usually focuses on common variants only, because genetic markers (SNPs) that show minor allele frequencies, lower than 0.05 , are generally excluded from the analysis.

The rap guanine nucleotide exchange factor 6 (RAPGEF6) is a protein-coding gene located on chromosome 13 in chickens (Gene ID: 101751943). Gene Ontology (GO) annotations associated with this gene consists of a guanyl-nucleotide exchange factor movement and a GTP-dependent protein requisite. The nucleotide sequence (15794705-15904202) specifies that this gene consists of 33 exons that encoded 109,498 amino acids (Accession No. NC_006100.3). The RAPGEF6 gene is preserved in transversely species comprising humans, chimpanzees, rhesus monkeys, dogs, cows, mice, rats, zebrafish, and Caenorhabditis elegans. Rap1, a member of the protein of the Ras-like superfamily of small GTPases, is involved in maintaining widespread cellular functions linked to cell adhesion, proliferation, differentiation, spreading, and endothelial junction control [24-30]. The accumulating results indicated that the RAPGEF6 gene has been established to perform a fundamental role in spermatogenesis [31,32], schizophrenia [33], and neuro psychiatric disorders [34] in mice, indicating that RAPGEF6 is essential for the reproductive development in mice. No polymorphisms in the RAPGEF6 gene that may affect economic traits in chicken have been investigated. Therefore, this study was planned to examine SNPs in the RAPGEF6 gene and their associations with the egg production trait to evaluate the effect of this gene on the egg-laying rate in chicken. This will provide further useful and detailed information that can be used to advance poultry breeding through the use of molecular marker-assisted selection programs.

\section{Materials and Methods}

\subsection{Ethics Statement}

This research was performed in strict accordance with the guidelines for experimental animals established by the Ministry of Science and Technology of China. All experimental procedures and research on animals were conducted in strict conformity with the recommendations in the Guide for the Care and Use of Laboratory Animals according to the regulations proclaimed by the Standing Committee of Hubei People's Congress (No. 5) and approved by the Biological Studies Animal Care Committee of Hubei Province, China as well as the ethics committee of Huazhong Agricultural University, Wuhan, China (Permission number: 4200896859).

\subsection{Experimental Birds}

A total of 1676 Chinese Jing Hong laying chicken from two populations were used for genotyping and marker-trait association analysis under this study. The first population (P1), comprising 858 healthy Chinese Jing Hong laying chickens (61-69 weeks old), were obtained from the poultry farm Jingzhou Yukou Poultry Industry Co. Ltd., Jingzhou-434020, Hubei, China. The other population (P2), comprising a total of 818 Chinese Jing Hong laying chickens (also 61-69 weeks old), were reared at Huadu Yukou Poultry Industry Co. Ltd., Beijing, China. These birds were raised individually in stair-step cages under a consistent environment with separated feed trays and egg collecting trays. The birds were fed by limited nutrition according to the percentage of their weights. The birds were fed a commercial corn-soybean-based iso-caloric and iso-nitrogenous diet, containing $2850 \mathrm{Kcal} \mathrm{ME} / \mathrm{kg}$ dry matter $(\mathrm{DM})$ and $16.83 \%$ crude protein $(\mathrm{CP})$. The required feed was supplied twice a day, at 7:00 a.m. and at 4:00 p.m., according to the Chinese Jing Hong laying chicken rearing manual. Safe drinking water was also made available at all times by a nipple drinker. All birds were kept in identical light/dark cycles that exposed them to $16 \mathrm{~h}$ of light per day. 


\subsection{Data Collection and Measured Traits}

The number of eggs produced from the individual experimental bird was recorded daily for 60 days duration (weeks 61-69). The egg-laying rate was calculated from data concerning the number of eggs produced by each hen using the following equation:

$$
\text { Egg }- \text { Laying rate }(\mathrm{LR}) \%=\frac{\text { Total number of eggs produced }}{\text { Days of production }} \times 100
$$

To construct the evolutionary relationships of the RAPGEF6 gene of chicken with other species, we also downloaded nucleotide sequences of different species from the National Centre Biotechnology Information (NCBI) (Rockville Pike Bethesda, MD, USA) and kept chicken as a reference. All collected sequences and their corresponding nucleotide sequences were aligned, and a phylogenetic tree was constructed using Molecular Evolutionary Genetics Analysis (MEGA) version 6 software with the maximum likelihood method [35]. The analysis results of the chickens' RAPGEF6 gene were compared with 16 species and the genetic similarity results were recorded.

\subsection{Blood Sample Collection and Genomic DNA Extraction}

Blood samples were collected from the wing vein in a tube containing ethylene diamine tetra acetic acid (EDTA), as an anticoagulant. All samples were collected in an ice box and subsequently preserved at $-20^{\circ} \mathrm{C}$ until further use. The genomic DNA was extracted according to the phenol-chloroform method as described by Sambrook and Russel, 2006 [36], with some minor modifications. The concentration and quality of the extracted DNA were quantified using the ND-2000 spectrophotometer (NanoDrop Co., Ltd., Thermo Fisher Scientific, Madison, WI, USA) and agarose gel electrophoreses, respectively. Only genomic DNA preparations within the ratios of 1.6-1.8 (A260/A280) and equilibrated to $50 \mathrm{ng} / \mu \mathrm{L}$ were used for the genotyping.

\subsection{Identification of SNPs Associated with Egg Production Traits Using GWAS}

Jing Hong parent hens showing extreme performance differences were used to detect SNP markers associated with egg-laying rates using the GWAS. A high-density SNP array was employed here to identify associated variants underlying egg production traits using the chicken 600K Affymetrix Axiom HD SNP-array (Aviagen Ltd., Midlothian, UK) to investigate whether the effects of these QTLs were associated with egg production traits [37]. The GWAS was performed using a total of 120 Jing Hong parent chickens from a total of 858 hens of the first population. The chickens of the first sixty and of the last sixty egg production traits were used for the GWAS. The first sixty and the last sixty were considered as control chickens and case group chickens, respectively. Two statistical models-a fixed-effect linear regression model and a mixed-effect linear model-were used to estimate the association effects of SNPs on each of the phenotypes. The significant and suggestive thresholds were set at $\left(p=2.09 \times 10^{-7}\right)$ and $\left(p=4.18 \times 10^{-6}\right)$, respectively. The two statistical models concurrently identified five genome-wide significant SNPs $(p<0.05)$ on egg production traits in these chickens. The global view of $p$-values for all SNP markers was visualized using a Manhattan and Quantile-Quantile (Q-Q) plot that was constructed for each trait using the "CM plot" package in the R software (version 3.5) [38]. A GWAS analysis was performed using the compressed mixed linear model [39] carried out using the TASSEL software package (version 5.0) (Ithaca, NY, USA) [40]. The genome-wide significance $p$ value threshold was determined by the "LD-adjusted" Bonferroni method [41]. Those five SNPs are all located in the RAPGEF6 gene.

\subsection{Genotyping by PCR-RFLP and Reconstruction of Haplotypes}

All experimental birds (P1 and P2) were then genotyped considering the identified SNP's location following the PCR-RFLP technique. A total of five primers were designed for the genotyping of 5 tag SNPs in the RAPGEF6 gene. Tabular description of five identified Database SNPs in the RAPGEF6 gene is shown in Supplementary Table S1. The RAPGEF6 gene (Gene Bank Accession No. 
NC_006100.3, Region: (15794705-15904202) reference sequence was used to design primers to amplify DNA fragments that contain those SNPs with the Oligo6 software. Primer synthesis was completed using Oligonucleotide synthesis technology of Sangon Biotech Co., Shanghai, China. A detailed description of primer sets and their corresponding products size with the location is that were used to genotype five tag SNPs is shown in Supplementary Table S2. The $10.0 \mu \mathrm{L}$ reaction mixture volume included $1.3 \mu \mathrm{L}$ of the DNA template, $0.15 \mu \mathrm{L}$ of each primer $\left(100 \mathrm{nmol} \mu \mathrm{L}^{-1}\right), 10 \times$ buffer $1.0 \mu \mathrm{L}$, dNTP $0.1 \mu \mathrm{L}$, rTaq $0.1 \mu \mathrm{L}$, and $7.2 \mu \mathrm{L}$ sterile distilled water used for PCR. The amplification program consisted of an Eppendorf thermal cycler that was programmed for an initial incubation temperature at $95{ }^{\circ} \mathrm{C}$ for $5 \mathrm{~min}$, followed by 35 cycles each of which included denaturing at $95^{\circ} \mathrm{C}$ for $30 \mathrm{~s}$, annealing at $50-55^{\circ} \mathrm{C}$ (Supplementary Table S2) for $30 \mathrm{~s}$, and an extension at $72{ }^{\circ} \mathrm{C}$ for $40 \mathrm{~s}$. A final extension at $72{ }^{\circ} \mathrm{C}$ for $7 \mathrm{~min}$ and then at $25^{\circ} \mathrm{C}$ for $30 \mathrm{~s}$ were carried out. After the reaction process was completed, the PCR products were separated on $1.5 \%(\mathrm{w} / \mathrm{v})$ agarose gel electrophoresis and stained with ethidium bromide and visualized in a BIO-RAD Image Lab gel documentation system (BIO-RAD, Hercules, CA, USA). The amplified PCR products included were digested by $0.03 \mu \mathrm{L}$ of 250 specific restriction enzymes (New England BioLabs Inc., Ipswich, MA, USA). The digestion mixture contained: $5 \mu \mathrm{L}$ of PCR products, $1 \mu \mathrm{L}$ of cut smart buffer, $4 \mu \mathrm{L}$ of DNAse free $\mathrm{ddH}_{2} \mathrm{O}$, and $3.0 \mathrm{U}$ of each enzyme. After that, it was incubated overnight at the manufacturer's instructed temperature for specific restriction enzyme's requirements. The genotype patterns were visualized from the digested products that were separated on $5 \%(\mathrm{w} / \mathrm{v})$ agarose gel electrophoresis and stained with ethidium bromide. The genotype pattern was recorded by the gel documentation system (BIO-RAD Image Lab) to check the genotype category of each chicken considering each SNP's position. The ingredients of SNPs in the RAPGEF6 gene PCR-RFLP optimized Restriction Enzyme $(R E)$ digestion mixture is shown in Supplementary Table S3. The restriction enzymes used in the present study and their respective restriction sites are given in Supplementary Table S4. Haplotypes were reconstructed among three significant SNPs (AX-75745366, AX-75745340, and AX-75745341) and association analysis of haplotypes were also performed based on two significant SNPs (AX-75745340 and AX-75745341) according to the genotyping data obtained from all experimental population of P1 and P2 used in the present study applying the PHASE 2.0 program [42]. The minimum haplotype frequency was set at $2 \%$.

\subsection{Polymorphism Evaluation}

The genotype and allele frequencies at each SNP site were calculated for all populations according to electrophoresis results of the genotype categorization. Genotypic frequencies of different PCR-RFLP patterns were estimated from the combination of different RFLP alleles generated based on the presence or absence of one or more restriction sites. Different genotypes were identified based on different patterns. Individual Jing Hong layer chickens were genotyped for the five SNPs at base positions of 15836649, 15843452, 15829057, 15845449, and 15829303 and termed SNPs; SNP-01 (T-15836649-C), SNP-02 (C-15843452-T), SNP-03 (A-15829057-G), SNP-04 (G-15845449-A), and SNP-05 (A-15829303-G). Genotype frequencies of the SNPs in the RAPGEF6 gene were analyzed by Microsoft Excel (MS Excel). Gene frequencies were calculated from genotypic frequencies. The test for the Hardy-Weinberg-equilibrium at each SNP site was conducted separately for the P1, P2, and P1 + P2 population, using the Haplo view version 4.2 software (http://www.broad.mit.edu/mpg/haploview/) [43]. Genotypic and allelic frequencies at each SNP site were calculated, with each polymorphism evaluated for the Hardy-Weinberg equilibrium using a Pearson's goodness-of-fit chi-square test (degree of freedom =1). We performed linkage disequilibrium (LD) analysis in order to characterize five causal SNPs in a strong LD region where three significant SNPs were identified by the solid spine algorithm in Haploview version 4.2 (Cambridge, MA, USA) as being clustered [43]. Gene homozygosity ( $\mathrm{Ho}$ ), heterozygosity $(\mathrm{He})$, the effective number of alleles $(\mathrm{Ne})$, and the polymorphism information content (PIC) were statistically analyzed using the POPGENE v. 1.32 software [44]. 


\subsection{Marker-Trait Association Analysis}

Association analyses of the five SNPs genotypes or haplotypes with Phenotypic data of egg-laying rate were performed in the Chinese Jing Hong layer chicken population using the General Linear Model Procedures (GLM) of the SAS statistical 9.2 software package (SAS Institute, Inc., Cary, NC, USA) [45]. Data were processed in MS Excel, and a linear mixed effect model procedure analyzed the genetic effects.

$$
\mathrm{Y}_{\mathrm{ijk}}=\mu+\mathrm{L}_{\mathrm{i}}+\mathrm{G}_{\mathrm{j}}+\mathrm{F}_{\mathrm{k}}+\mathrm{e}_{\mathrm{ijk}}
$$

where $Y_{i j k}$ is phenotypic value of the target trait (e.g., egg-laying rate), $\mu$ is population mean of egglaying rate, $L_{i}$ is fixed effect of the line, $G_{j}$ is fixed effect of the SNP genotype or haplotype, $F_{k}$ is random effect of the family, and $\mathrm{e}_{\mathrm{ijk}}$ is the overall error term.

Type III sum of squares was used in each test. The threshold for significance was set at $p<0.05$ and for high significance at $p<0.01$. All values are presented as least square means with standard errors of the mean (LSM \pm SEM). Means were compared for significant differences using Duncan's Multiple Range Test [46].

\section{Results}

\subsection{Identification of Most Significant SNPS in RAPGEF6 Gene by GWAS}

The global view of $p$ values for all SNP markers was visualized by a Manhattan plot, as shown in Figure 1. After performing a GWAS, there was no dramatic deviation between observed and expected - $\log 10$ ( $p$ value) in the Q-Q (Quantile-Quantile) plot (Figure 2), suggesting that there was little or no evidence of residual population structure effects in test statistic inflation. GWAS results of 120 laying birds show that five identified SNPs in chromosome 13 are associated with egg production traits, which are all located in gene RAPGEF6. This gene could serve as a new candidate gene for the egg-laying rate during the late period of laying, yet their roles need to be verified in further studies. The positions of the SNPs and information were obtained based on the ICGSC annotation of the Gallus gallus genome version 4.0 and the gene within 109,498 (15794705-15904202) base pairs flanking the associated SNPs that were chosen for analysis. A tabular description of five identified database SNPs in the RAPGEF6 gene is shown in Supplementary Table S1. The selected significantly associated SNPs by GWAS were further genotyped for validation using an PCR-RFLP approach, and association studies were performed with egg-laying rate trait in two expanded populations.

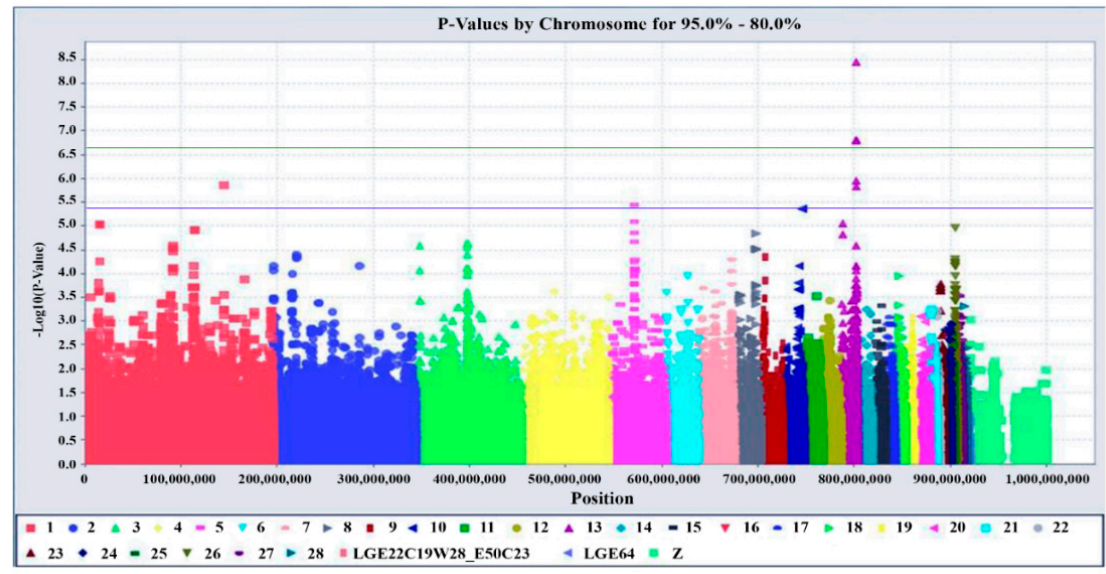

Figure 1. The Manhattan plot shows the association of single nucleotide polymorphisms with egg production traits. Each dot represents one SNP. The figure illustrated the level of statistical significance (y-axis), as measured by the negative log of the corresponding $p$ value for each single nucleotide polymorphism (SNP). Each typed SNPs indicate dots of different colors, which are arranged by chromosomal location (x-axis). Imputation was performed on chromosome 13 using only the data of 
120 genomes. The highlighted green line indicates the threshold of 5\% Bonferroni genome-wide significance $\left(p=2.09 \times 10^{-7}\right)$, and the underlined blue line shows the limit of symbolic genome-wide significance $\left(p=4.18 \times 10^{-6}\right)$, respectively.

a

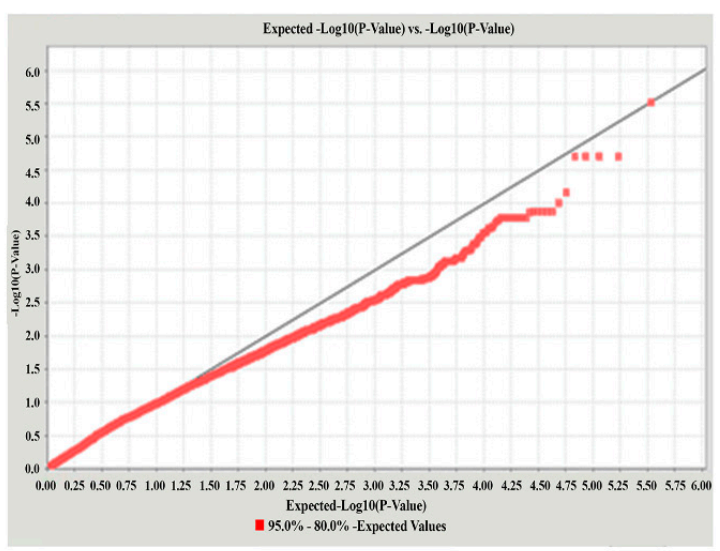

b

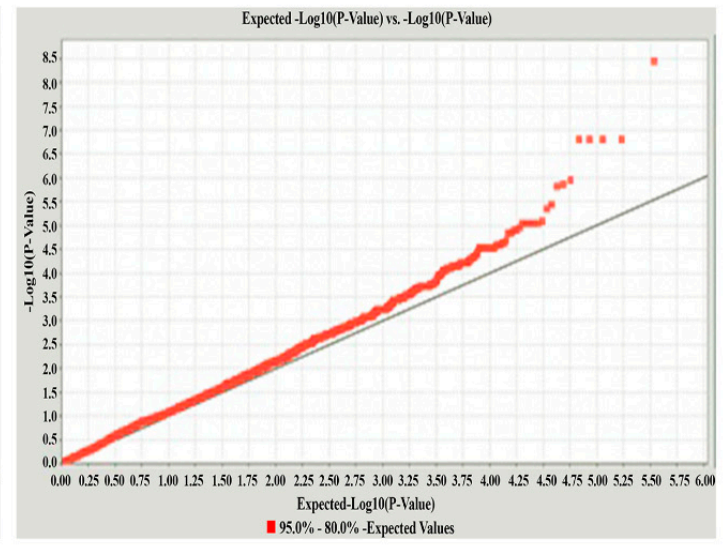

Figure 2. Q-Q (Quantile-Quantile) plots for quality control check and visualizing crude association. (a) Unadjusted model; $\lambda=1.0142$ and (b) Adjusted model for PCs, Age and Sex; $\lambda=1.0032$. The plots illustrate the relationship between observed $\log 10$ ( $p$ value) in the y-axis and expected $\log 10$ ( $p$ value) in $\mathrm{x}$-axis test statistics and are used as a tool for visualizing appropriate control of population substructure and the presence of association. The left panel (a) is based on an unadjusted model, where the deviation is below expected, while the right panel (b) is based on an adjusted model for potential cofounders, which brings the tail closer to the $\mathrm{y}=\mathrm{x}$ line. The observed extreme statistics are suggestive of an association. Data generally falling on the $y=x$ lines suggest no clear systemic bias. Unstandardized $\lambda^{\prime} \mathrm{s}$ are reported. PCs: principal components.

\subsection{Phylogenetic Analysis}

The nucleotide sequences were analyzed for the phylogenetic tree using MEGA version 6 software. The nucleotide sequences of the RAPGEP6 gene of chicken (Gallus gallus), t emperor penguin (Aptenodytes forsteri), Adelie penguins (Pygoscelis adeliae), Golden Eagle (Aquila chrysaetos canadensis), bald eagle (Haliaeetus leucocephalus), common pigeon (Columba livia), swan goose (Anser cygnoides domesticus), mallard duck (Anas platyrhynchos), society (or Bengalese) finches (Lonchura striata domestica), hooded crow (Corvus cornix cornix), american crow (Corvus brachyrhynchos), ground tit (Pseudopodoces humilis), eurasian blue tit (Cyanistes caeruleus), great tit (Parus major), Japanese quail (Coturnix japonica), melmeted guineafowl (Numida meleagris), and wild turkey (Meleagris gallopavo) were aligned, and a phylogenetic tree was constructed to know the evolutionary relationship with other species using MEGA version 6 software (Pennsylvania State University, PA, USA) with the Unweighted Pair Group Method with Arithmetic Mean (UPGMA) method. The analysis results of the chicken RAPGEF6 gene were compared with 16 species, and the genetic similarity results were recorded. The UPGMA phylogenetic tree showed that the chicken RAPGEP6 gene was closely related to the RAPGEP6 gene of the guineafowl (Numida meleagris) than that of other studied species (Figure 3). 


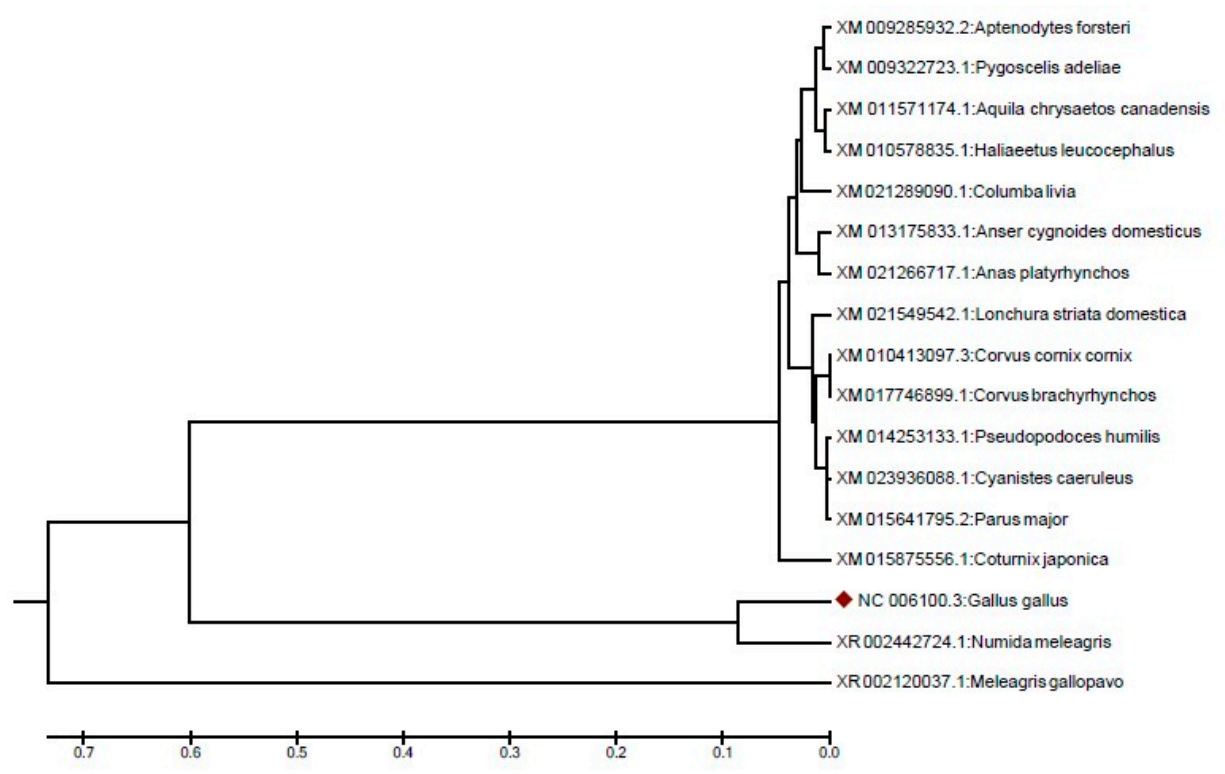

Figure 3. The UPGMA (Unweighted Pair Group Method with Arithmetic Mean) evolutionary relationship tree of chicken (Gallus gallus) RAPGEP6 gene with different species.

\subsection{Genotyping by PCR-RFLP and Reconstruction of Haplotypes}

The genotype patterns of the SNPs in the RAPGEF6 gene were checked using the PCR-RFLP technique and found three genotype patterns in SNP AX-75745366 (TT, TC, and CC) and two genotype pattern in SNP AX-75745380 (CC and CT), AX-75745340 (AA and AG), AX-75745388 (GG and AA) and AX-75745341 (AG and GG) (Supplementary Figures S1-S5). The genotypic and allelic frequencies of each identified SNP in the RAPGEF6 gene are presented in Table 1 . Haplotypes were reconstructed based on three significant SNPs-SNP-01: AX-75745366 (T15836649C), SNP-03: AX-75745340 (A15829057G), and SNP-05: AX-75745341 (A15829303G)-and their frequencies among all studied individuals are shown in Table 2. A total of eight haplotypes were constructed, in which the most abundant three haplotypes were $H 1$ (TAG), H2 (CAG), and H3 (TAA), which accounted for 94.77, 86.06, and 90.55\% of the genetic information in P1, P2, and P1 + P2 populations, respectively. Haplotype H1 (TAG) was predominant in all groups of the population studied. Another haplotype reconstruction was performed based on two significant SNPs-SNP-03: AX-75745340 (A15829057G) and SNP-05: AX-75745341 (A15829303G)-according to these genotyping data, and four haplotypes (AAGG, AAAG, AGGG, and AGAG) were identified among the individuals. For the P1 population, the haplotype present at the highest frequency was the AAGG haplotype (0.84), with the AAAG haplotype is the next most frequent (0.07), followed by AGAG (0.06), and AGGG haplotype is the lowest frequent (0.03). For the P2 population, the haplotype present at the highest frequency was the AAGG haplotype (0.65), with the AGAG haplotype being the next most frequent (0.14), followed by AAAG (0.13), and finally the AGGG haplotype as the lowest frequent (0.08). For the P1 + P2 population, the haplotype present at the highest frequency was the AAGG haplotype (0.75), with the AAAG haplotype is the next most frequent (0.1), followed by AGAG (0.09), and AGGG haplotype is the lowest (0.06). 
Table 1. Genotypic and allelic frequencies with Hardy-Weinberg equilibrium (HWE) test at the SNP locus of RAPGEF6 gene in the Chinese Jing Hong chicken population.

\begin{tabular}{|c|c|c|c|c|c|c|c|c|c|}
\hline \multirow{5}{*}{$\begin{array}{c}\text { SNPs (Location) } \\
\text { SNP-01 } \\
(\mathrm{AX}-75745366)\end{array}$} & \multirow{5}{*}{$\begin{array}{c}\text { Population } \\
\\
\text { P1 } \\
\text { P2 } \\
\text { P1 + P2 }\end{array}$} & \multirow{3}{*}{$\begin{array}{c}n \\
858\end{array}$} & \multicolumn{3}{|c|}{ Genotype Frequency } & \multicolumn{2}{|c|}{ Allele Frequency } & \multirow[t]{2}{*}{$\chi^{2}$ (HWE) } & \multirow[t]{2}{*}{$p$ Value } \\
\hline & & & TT & TC & CC & $\mathrm{T}$ & C & & \\
\hline & & & $0.33(282)$ & $0.52(450)$ & 0.15 (126) & 0.59 (1014) & 0.41 (702) & 6.17 * & 0.0130 \\
\hline & & 818 & $0.32(265)$ & 0.54 (438) & 0.14 (115) & $0.59(968)$ & $0.41(668)$ & $9.57 *$ & 0.0020 \\
\hline & & 1676 & $0.33(547)$ & $0.53(888)$ & $0.14(241)$ & 0.59 (1982) & $0.41(1370)$ & $15.51 *$ & 0.0001 \\
\hline \multirow{4}{*}{$\begin{array}{c}\text { SNP-02 } \\
(\mathrm{AX}-75745380)\end{array}$} & & & CC & CT & TT & C & $\mathrm{T}$ & & \\
\hline & P1 & 858 & 0.81 (697) & 0.19 (161) & - & 0.91 (1555) & 0.09 (161) & 9.20 * & 0.0024 \\
\hline & P2 & 818 & $0.82(668)$ & 0.18 (150) & - & 0.91 (1486) & 0.09 (150) & $8.33 *$ & 0.0039 \\
\hline & $\mathrm{P} 1+\mathrm{P} 2$ & 1676 & $0.81(1365)$ & $0.19(311)$ & - & $0.91(3041)$ & $0.09(311)$ & $17.53 *$ & 0.0000 \\
\hline \multirow{4}{*}{$\begin{array}{c}\text { SNP-03 } \\
\text { (AX-75745340) }\end{array}$} & & & AA & AG & GG & A & G & & \\
\hline & P1 & 858 & $0.91(782)$ & $0.09(76)$ & - & $0.96(1640)$ & $0.04(76)$ & $1.84^{\mathrm{NS}}$ & 0.1746 \\
\hline & P2 & 818 & 0.78 (642) & $0.22(176)$ & - & 0.89 (1460) & $0.11(176)$ & 11.89 * & 0.0006 \\
\hline & $\mathrm{P} 1+\mathrm{P} 2$ & 1676 & 0.85 (1424) & 0.15 (252) & - & $0.92(3100)$ & $0.08(252)$ & 11.08 * & 0.0009 \\
\hline \multirow{4}{*}{$\begin{array}{c}\text { SNP-04 } \\
\text { (AX-75745388) }\end{array}$} & & & GG & GA & AA & G & A & & \\
\hline & P1 & 858 & $0.49(421)$ & 0.51 (437) & - & 0.75 (1279) & 0.25 (437) & $100.16^{*}$ & 0.0000 \\
\hline & P2 & 818 & $0.50(405)$ & $0.50(413)$ & - & 0.75 (1223) & 0.25 (413) & $93.28 *$ & 0.0000 \\
\hline & $\mathrm{P} 1+\mathrm{P} 2$ & 1676 & $0.49(826)$ & $0.51(850)$ & - & $0.75(2502)$ & $0.25(850)$ & $193.44 *$ & 0.0000 \\
\hline \multirow{4}{*}{$\begin{array}{c}\text { SNP-05 } \\
\text { (AX-75745341) }\end{array}$} & & & $\mathrm{AA}$ & AG & GG & A & G & & \\
\hline & P1 & 858 & - & $0.12(104)$ & $0.88(754)$ & $0.06(104)$ & $0.94(1612)$ & $3.57 \mathrm{NS}$ & 0.0588 \\
\hline & P2 & 818 & - & $0.27(223)$ & 0.73 (595) & 0.14 (223) & 0.86 (1413) & 20.37 * & 0.0000 \\
\hline & $\mathrm{P} 1+\mathrm{P} 2$ & 1676 & - & $0.20(327)$ & $0.80(1349)$ & 0.10 (327) & $0.90(3025)$ & $19.58 *$ & 0.0000 \\
\hline
\end{tabular}

P1 = First population, P2 = Second population, P1 + P2 = Both first and second population, $n=$ Number of individual, SNP = Single nucleotide polymorphism, RAPGEF6 = Rap Guanine Nucleotide Exchange Factor $6{ }^{*} p<0.05$ was accepted to be statistically significant when the data were analyzed using a Pearson's goodness-of-fit chi-square test (degree of freedom $=1$ ), NS $=$ Non-significant at $p \geq 0.5$. 
Table 2. Haplotypes inferred based on the three SNPs and frequencies in RAPGEF6 gene of Chinese Jing Hong chicken population.

\begin{tabular}{ccccccc}
\hline \multirow{2}{*}{ Haplotype } & \multicolumn{3}{c}{ Polymorphism Site } & \multicolumn{3}{c}{ Frequency in Population } \\
\cline { 2 - 7 } & T15836649C & A15829057G & A15829303G & P1 & P2 & (P1 + P2) \\
\hline H1 & T & A & G & 0.5378 & 0.4762 & 0.5089 \\
H2 & C & A & G & 0.3829 & 0.3467 & 0.3644 \\
H3 & T & A & A & 0.0270 & 0.0377 & 0.0322 \\
H4 & T & G & A & 0.0167 & 0.0480 & 0.0316 \\
H5 & T & G & G & 0.0095 & 0.0298 & 0.0186 \\
H6 & C & G & G & 0.0093 & 0.0109 & 0.0106 \\
H7 & C & G & A & 0.0087 & 0.0189 & 0.0144 \\
H8 & C & A & A & 0.0081 & 0.0318 & 0.0193 \\
\hline
\end{tabular}

Haplotype: H1 (TAG), H2 (CAG), H3 (TAA), H4 (TGA), H5 (TGG), H6 (CGG), H7 (CGA), H8 CAA).

\subsection{Frequencies of Genotypes and Alleles at the SNP Locus}

The genotypic and allelic frequencies of each identified SNP in the RAPGEF6 gene are presented in Table 1. For the SNP AX-75745366 the frequency of allele T was higher than allele C, with the frequency of genotype TC being higher than genotype TT and CC in all populations. For the SNP AX-75745380, the frequency of allele $C$ was notably higher than allele $T$, with the frequency of genotype $C C$ being predominantly higher than genotype CT in all population. For the SNP AX-75745340, the frequency of allele A was notably higher than allele G, with the frequency of genotype AA being predominantly higher than genotype AG in all populations. For the SNP AX-75745388, the frequency of allele G was higher than allele A, with the frequency of genotype GA being higher than genotype GG in all populations. For the SNP AX-75745341, the frequency of allele G was notably higher than allele A, with the frequency of genotype GG being predominantly higher than genotype AG in all populations. The whole population was found to exhibit significant genetic disequilibrium $(p \geq 0.05)$, with the exception of the P1 population in the SNP site AX-75745340 and AX-75745341 between concern alleles in the RAPGEF6 gene. This shows a low genetic diversity in the population, which might result from the cause of selection. As shown in Table 3, the gene homozygosity ( $\mathrm{Ho}$ ) was higher than gene heterozygosity $\mathrm{(He}$ ) for all of the locus as well as for all of the population, with the effective allele numbers (Ne). The value of polymorphism information content (PIC) was not higher for all of the locus as well as for all of the population. The Hardy-Weinberg equilibrium and the average population genetics parameters considering all the SNPs (i.e., $\mathrm{Ho}, \mathrm{He}$, Ne and PIC values) were $0.75,0.25,1.4$, and 0.2 in P1; 0.71, 0.29, 1.46, and 0.24 in P2; and 0.73, 0.27, 1.43, and 0.22 in P1 + P2 populations, respectively. The PIC was not higher and the value of PIC for $\mathrm{He}$ in all groups of the population were $0.1074,0.2077$, and 0.1606 , respectively.

Table 3. Polymorphism information analysis of the SNPs in RAPGEF6 gene in the Chinese local Jing Hong chicken population.

\begin{tabular}{ccccccc}
\hline $\begin{array}{c}\text { SNPs } \\
\text { (Location) }\end{array}$ & Population & $\begin{array}{c}\text { Number of } \\
\text { Chickens }(\boldsymbol{n})\end{array}$ & $\begin{array}{c}\text { Gene } \\
\text { Homozygosity } \\
\text { (Ho) }\end{array}$ & $\begin{array}{c}\text { Gene } \\
\text { Heterozygosity } \\
\text { (He) }\end{array}$ & $\begin{array}{c}\text { Effective } \\
\text { Allele } \\
\text { Number (Ne) }\end{array}$ & $\begin{array}{c}\text { Polymorphism } \\
\text { Information } \\
\text { Content (PIC) }\end{array}$ \\
\hline SNP-01 & P1 & 858 & 0.5165 & 0.4835 & 1.9360 & 0.3666 \\
$($ AX-75745366) & P2 & 818 & 0.5168 & 0.4832 & 1.9349 & 0.3665 \\
& P1 + P2 & 1676 & 0.5167 & 0.4833 & 1.9355 & 0.3665 \\
\hline SNP-02 & P1 & 858 & 0.8300 & 0.1700 & 1.2049 & 0.1556 \\
$($ AX-75745380) & P2 & 818 & 0.8334 & 0.1666 & 1.1998 & 0.1527 \\
\hline PNP-03 & P1 & 1676 & 0.8317 & 0.1683 & 1.2024 & 0.1542 \\
\hline (AX-75745340) & P2 & 858 & 0.9153 & 0.0847 & 1.0925 & 0.0811 \\
\hline
\end{tabular}


Table 3. Cont

\begin{tabular}{ccccccc}
\hline $\begin{array}{c}\text { SNPs } \\
\text { Location) }\end{array}$ & Population & $\begin{array}{c}\text { Number of } \\
\text { Chickens }(\boldsymbol{n})\end{array}$ & $\begin{array}{c}\text { Gene } \\
\text { Homozygosity } \\
\text { (Ho) }\end{array}$ & $\begin{array}{c}\text { Gene } \\
\text { Heterozygosity } \\
\text { (He) }\end{array}$ & $\begin{array}{c}\text { Effective } \\
\text { Allele } \\
\text { Number (Ne) }\end{array}$ & $\begin{array}{c}\text { Polymorphism } \\
\text { Information } \\
\text { Content (PIC) }\end{array}$ \\
\hline SNP-04 & P1 & 858 & 0.6204 & 0.3796 & 1.6119 & 0.3076 \\
$(\mathrm{AX}-75745388)$ & $\mathrm{P} 2$ & 818 & 0.6226 & 0.3774 & 1.6063 & 0.3062 \\
& $\mathrm{P} 1+\mathrm{P} 2$ & 1676 & 0.6214 & 0.3786 & 1.6092 & 0.3069 \\
\hline SNP-05 & $\mathrm{P} 1$ & 858 & 0.8861 & 0.1139 & 1.1285 & 0.1074 \\
$(\mathrm{AX}-75745341)$ & $\mathrm{P} 2$ & 818 & 0.7645 & 0.2355 & 1.3080 & 0.2077 \\
& $\mathrm{P} 1+\mathrm{P} 2$ & 1676 & 0.8239 & 0.1761 & 1.2137 & 0.1606 \\
\hline
\end{tabular}

P1 = First population, P2 = Second population, P1 + P2 = Both first and second population

3.5. Association Analysis between the SNP Genotypes in RAPGEF6 Gene with Egg-Laying Performance in Jing Hong Hens Breed

Statistical analyses were performed to test the significance of the difference of genotype effect on egg production performance among the five SNPs of RAPGEF6 gene in Chinese local Jing Hong layer chickens. The association analysis results were shown between the SNP genotypes in the RAPGEF6 gene and egg-laying rate (LR) by 60-day laying period in the Chinese Jing Hong layer chickens, and the least square means and standard error of means $(\mathrm{LSM} \pm \mathrm{SEM})$ of different genotypes for each SNPs are listed in Table 4 . The results showed that the significant $(p<0.0001)$ association with 60 days egg-laying rate were found at the loci AX-75745366 (T15836649C), AX-75745340 (A15829057G), and AX-75745341 (A15829303G) in all populations of Chinese local Jing Hong layer chicken, which are treated as SNP-01, SNP-03, and SNP-05 respectively. The SNP-01, SNP-03, and SNP-05 was significantly associated with the 60 days of egg production. In the SNP AX-75745366 (T15836649C), the significantly highest $(p<0.0001)$ egg-laying rate was shown in chickens with genotypes TC $(80.50 \pm 0.86)$, followed by the genotypes TT (78.63 \pm 1.08$)$, and were the lowest with genotypes CC (72.61 \pm 1.62$)$ in P1 population. The genotypes TT $(85.30 \pm 1.02$ and $81.86 \pm 0.75)$ showed the highest egg-laying rate in P2 and P1 + P2 population, followed by the genotype TC $(80.49 \pm 0.79$ and $80.49 \pm 0.59)$, and was the lowest with genotypes CC (76.40 \pm 1.54 and $74.42 \pm 1.13)$, respectively. In the SNP AX-75745340 (A15829057G), the significantly higher $(p<0.0001)$ egg-laying rate was found in chickens with the genotypes AA $(79.99 \pm 0.64,83.28 \pm 0.65$, and $81.47 \pm 0.46)$ in P1, P2, and P1 + P2 population compared with the genotype AG $(65.69 \pm 2.06,74.87 \pm 1.24$, and $72.10 \pm 1.09)$, respectively. In the SNP AX-75745341 (A15829303G), the significantly highest $(p<0.0001)$ numbers of egg production were seen in chickens with the genotypes GG $(79.59 \pm 0.66,84.09 \pm 0.67$, and $81.57 \pm 0.47)$ in $\mathrm{P} 1, \mathrm{P} 2$, and $\mathrm{P} 1+\mathrm{P} 2$ population compared with genotype AG $(72.43 \pm 1.79,74.50 \pm 1.09$, and $73.84 \pm 0.96)$, respectively. There was no significant association for the SNP AX-75745380 (C15843452T) and AX-75745388 (G15845449A) for the egg-laying rate for the studied 60-day laying period $(p \geq 0.05)$.

An association analysis between the haplotypes (AAGG, AAAG, AGGG, and AGAG) inferred based on two significant loci-AX-75745340 (A15829057G) and AX-75745341 (A15829303G) - and the egg-laying rate by day 60 in P1, P2, and P1 + P2 population are shown in Table 5. In the case of P1, among the haplotypes, haplotype AAAG was found to be correlated with the significantly highest $(p<0.0001)$ egg-laying rate $(83.03 \pm 2.33)$ for the 60-day laying period, followed by haplotype AAGG $(79.79 \pm 0.40)$ and AGGG $(75.85 \pm 3.24)$; the lowest levels were associated with haplotype AGAG $(59.07 \pm 2.62)$. However, in case of $\mathrm{P} 2$, among the four haplotypes, haplotype AAGG was shown to be markedly associated with the significantly highest $(p<0.0001)$ egg-laying rate $(84.50 \pm 0.70)$ for the 60-day laying period, followed by haplotype AGGG (80.46 \pm 2.07$)$ and AAAG (77.27 \pm 1.56$)$; the lowest levels were associated with haplotype AGAG (71.90 \pm 1.51$)$. Finally, in case of P1+P2 population, among the four haplotypes, haplotype AAGG was found to be correlated with the significantly highest $(p<0.0001)$ egg-laying rate $(81.76 \pm 0.49)$ for the 60 -day laying period, followed by haplotype AAAG $(79.28 \pm 1.34)$ and AGGG $(78.94 \pm 1.81)$; the lowest levels were associated with haplotype AGAG $(68.23 \pm 1.36)$. 
Table 4. Association analysis between the genotypes of five polymorphisms in chicken RAPGEF6 gene and egg-laying rates in the Chinese Jing Hong chicken population.

\begin{tabular}{|c|c|c|c|c|c|c|c|c|}
\hline \multirow{2}{*}{ SNPs (Location) } & \multirow{2}{*}{ Population } & \multirow{2}{*}{$n$} & \multirow{2}{*}{\multicolumn{3}{|c|}{ Genotype Frequency $(\mathrm{LSM} \pm \mathrm{SEM})$}} & \multicolumn{3}{|c|}{$F$-value, $p$ Value and Level of Significance } \\
\hline & & & & & & $F$-Value & $p$ Value & Level of Significance \\
\hline \multirow{4}{*}{$\begin{array}{c}\text { SNP-01 } \\
\text { (AX-75745366) }\end{array}$} & & & TT & $\mathrm{TC}$ & $\mathrm{CC}$ & & & \\
\hline & P1 & 858 & $78.63 \pm 1.08^{\mathrm{a}}(282)$ & $80.50 \pm 0.86^{\mathrm{a}}(450)$ & $72.61 \pm 1.62^{b}(126)$ & 9.25 & $<0.0001$ & $* * *$ \\
\hline & P2 & 818 & $85.30 \pm 1.02^{\mathrm{a}}(265)$ & $80.49 \pm 0.79^{\mathrm{b}}(438)$ & $76.40 \pm 1.54^{\mathrm{c}}(115)$ & 13.29 & $<0.0001$ & $* * *$ \\
\hline & $\mathrm{P} 1+\mathrm{P} 2$ & 1676 & $81.86 \pm 0.75^{\mathrm{a}}(547)$ & $80.49 \pm 0.59^{a}(888)$ & $74.42 \pm 1.13^{\mathrm{b}}(241)$ & 15.67 & $<0.0001$ & $* * *$ \\
\hline \multirow{4}{*}{$\begin{array}{c}\text { SNP-02 } \\
(\mathrm{AX}-75745380)\end{array}$} & & & $\mathrm{CC}$ & $\mathrm{CT}$ & TT & & & \\
\hline & P1 & 858 & $79.20 \pm 0.70(697)$ & $76.67 \pm 1.45(161)$ & - & 2.49 & 0.1151 & NS \\
\hline & P2 & 818 & $81.18 \pm 0.65(668)$ & $82.78 \pm 1.37(150)$ & - & 1.12 & 0.2896 & NS \\
\hline & $\mathrm{P} 1+\mathrm{P} 2$ & 1676 & $80.17 \pm 0.48(1365)$ & $79.62 \pm 1.00(311)$ & - & 0.25 & 0.6197 & NS \\
\hline \multirow{4}{*}{$\begin{array}{c}\text { SNP-03 } \\
\text { (AX-75745340) }\end{array}$} & & & AA & AG & GG & & & \\
\hline & P1 & 858 & $79.99 \pm 0.64^{\mathrm{a}}(782)$ & $65.69 \pm 2.06^{\mathrm{b}}(76)$ & - & 44.03 & $<0.0001$ & $* * *$ \\
\hline & P2 & 818 & $83.28 \pm 0.65^{\mathrm{a}}(642)$ & $74.87 \pm 1.24^{\mathrm{b}}(176)$ & - & 36.30 & $<0.0001$ & $* * *$ \\
\hline & $\mathrm{P} 1+\mathrm{P} 2$ & 1676 & $81.47 \pm 0.46^{\mathrm{a}}(1424)$ & $72.10 \pm 1.09^{b}(252)$ & - & 62.55 & $<0.0001$ & $* * *$ \\
\hline \multirow{4}{*}{$\begin{array}{c}\text { SNP-04 } \\
\text { (AX-75745388) }\end{array}$} & & & GG & GA & GG & & & \\
\hline & P1 & 858 & $78.92 \pm 0.90(421)$ & $78.54 \pm 0.88(437)$ & - & 0.09 & 0.7633 & NS \\
\hline & P2 & 818 & $81.08 \pm 0.83(405)$ & $81.86 \pm 0.83(413)$ & - & 0.45 & 0.5015 & NS \\
\hline & $\mathrm{P} 1+\mathrm{P} 2$ & 1676 & $79.97 \pm 0.61(826)$ & $80.15 \pm 0.61(850)$ & - & 0.04 & 0.8355 & NS \\
\hline \multirow{4}{*}{$\begin{array}{c}\text { SNP-05 } \\
\text { (AX-75745341) }\end{array}$} & & & AA & AG & GG & & & \\
\hline & P1 & 858 & - & $72.43 \pm 1.79^{b}(104)$ & $79.59 \pm 0.66^{\mathrm{a}}(754)$ & 14.09 & $<0.0001$ & $* * *$ \\
\hline & P2 & 818 & - & $74.50 \pm 1.09^{\mathrm{b}}(223)$ & $84.09 \pm 0.67^{\mathrm{a}}(595)$ & 56.57 & $<0.0001$ & $* * *$ \\
\hline & $\mathrm{P} 1+\mathrm{P} 2$ & 1676 & - & $73.84 \pm 0.96^{\mathrm{b}}(327)$ & $81.57 \pm 0.47^{\mathrm{a}}(1349)$ & 51.96 & $<0.0001$ & $* * *$ \\
\hline
\end{tabular}

P1 = First population, P2 = Second population, P1 + P2 = Total (both first and second) population, $n=$ Number of individual, SNP = Single nucleotide polymorphism, RAPGEF6 = Rap Guanine Nucleotide Exchange Factor 6, LSM = Least squares of mean, SEM = Standard error of mean, G = Genotypes (i.e., TT, TC, CC). The values in parentheses indicate the numbers of chicken for their corresponding group. ${ }^{*}=$ Significant at $p<0.1{ }^{* *}=$ Significant at $p<0.01,{ }^{* * *}=$ Significant at $p<0.001,{ }^{\mathrm{a}, \mathrm{b}, \mathrm{c}}=$ LSM values bearing different letters in each column are significantly different at ${ }^{* * *}$ and ${ }^{* * *}, \mathrm{NS}=$ Non-significant at $p>0.5$. 
Table 5. Association analysis between the haplotype inferred through AX-75745340 (A15829057G) \& AX-75745341 (A15829303G) in chicken RAPGEF6 gene and egg-laying rate of Chinese Jing Hong chicken population.

\begin{tabular}{|c|c|c|c|c|c|c|c|c|c|}
\hline \multirow{3}{*}{ Trait } & \multirow{3}{*}{ Population } & \multirow{3}{*}{$n$} & \multirow{2}{*}{\multicolumn{4}{|c|}{ Haplotype Frequency $(\mathrm{LSM} \pm$ SEM) }} & \multicolumn{3}{|c|}{$F$-Value, $p$ Value and Level of Significance } \\
\hline & & & & & & & $F$-Value & $p$ Value & Level of Significance \\
\hline & & & H1 (AAGG) & H2 (AAAG) & H3 (AGGG) & H4 (AGAG) & & & \\
\hline \multirow[t]{3}{*}{ Laying Rate } & P1 & 858 & $79.79 \pm 0.40^{\mathrm{ab}}(724)$ & $83.03 \pm 2.33^{\mathrm{a}}(58)$ & $75.85 \pm 3.24^{\mathrm{b}}(30)$ & $59.07 \pm 2.62^{c}(46)$ & 20.963 & $<0.0001$ & $* * *$ \\
\hline & P2 & 818 & $84.50 \pm 0.70^{\mathrm{a}}(534)$ & $77.27 \pm 1.56^{\mathrm{b}}(108)$ & $80.46 \pm 2.07^{\mathrm{ab}}(61)$ & $71.90 \pm 1.51^{\mathrm{c}}(115)$ & 22.226 & $<0.0001$ & $* * *$ \\
\hline & $\mathrm{P} 1+\mathrm{P} 2$ & 1676 & $81.76 \pm 0.49^{\mathrm{a}}(1258)$ & $79.28 \pm 1.34^{\mathrm{a}}(166)$ & $78.94 \pm 1.8^{a}(91)$ & $68.23 \pm 1.36^{\mathrm{b}}(161)$ & 0.246 & $<0.0001$ & $* * *$ \\
\hline
\end{tabular}

P1 = First population, P2 = Second population, P1 + P2 = Total (both first and second) population, $n=$ Number of individual, SNP = Single nucleotide polymorphism, RAPGEF6 = Rap Guanine Nucleotide Exchange Factor 6, LSM = Least squares of mean, SEM = Standard error of mean, H = Haplotypes (i.e., AAGG, AAAG, AGGG and AGAG). The values in parentheses indicate the number of chicken for their corresponding group. ${ }^{*}=$ Significant at $p<0.1,{ }^{* *}=$ Significant at $p<0.01, * * *=$ Significant at $p<0.001,{ }^{\text {a }}$, b, c $=$ LSM values within a row for each haplotype lacking a common superscript differ significantly $p<0.05)$. 


\subsection{Linkage Disequilibrium (LD) Analysis of SNPs in RAPGEF6 Gene in Chinese Jing Hong Chicken Population}

Haplotype block and LD structures were generated from the five SNPs genotyped in the RAPGEF6 gene from chicken populations (Figure $4 a-c)$. Pairwise coefficients of linkage disequilibrium $\left(\mathrm{D}^{\prime}\right)$ values are shown between polymorphisms, which were calculated from the genotypic data of $\mathrm{P} 1=858$, $\mathrm{P} 2=818$, and P1 $+\mathrm{P} 2=1676$ chickens. The haplotypes block was defined by using the default setting of the Haploview software (Broad Institute, Cambridge, MA, USA). In the P1 population, there were two variants: AX-75745341A/G and AX-75745341A/G showed non-significant LD with each other with low $\mathrm{D}^{\prime}\left(\mathrm{D}^{\prime}=13\right)$ and spanning $0 \mathrm{~kb}$ in only one block 1 . In the case of $\mathrm{P} 2$ population, there were three variants: AX-75745340A/G, AX-75745341A/G, and AX-75745366T/C showed significant LD with each other with highly strong $\mathrm{D}^{\prime}\left(\mathrm{D}^{\prime}=93\right.$ and 83 ) and spanning $7 \mathrm{~kb}$ in block 1 only. Finally, in the case of the P1 + P2 population, two variants were found: AX-75745340A/G and AX-75735341/G showed significant $\mathrm{LD}$ with each other with strong $\mathrm{D}^{\prime}\left(\mathrm{D}^{\prime}=69\right)$ and spanning $0 \mathrm{~kb}$ in block 1 only.

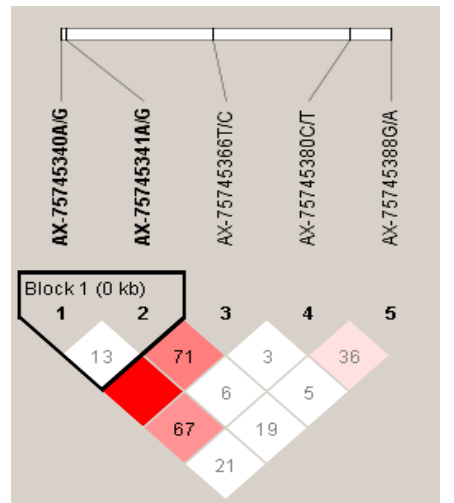

(a)

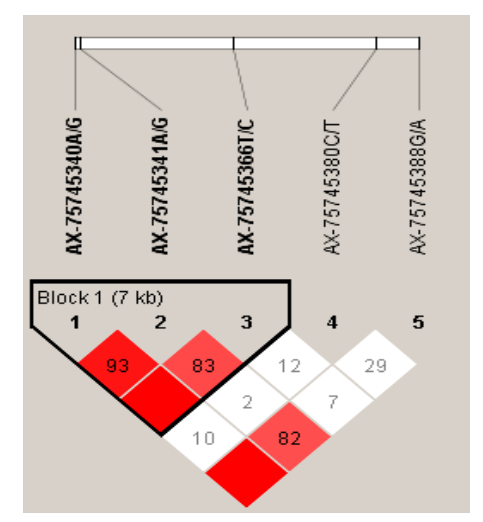

(b)

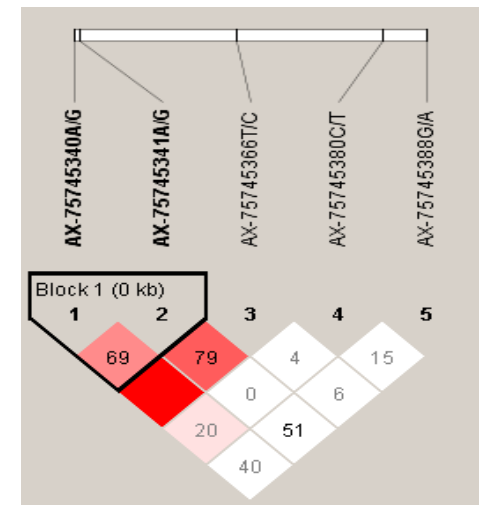

(c)

Figure 4. (a-c) Linkage disequilibrium (LD) of single nucleotide polymorphisms (SNPs) at the RAPGEF6 gene in egg-laying rate in Chinese Jing Hong Chicken. Pairwise correlation ( $\left.\mathrm{D}^{\prime}\right)$ values are shown between polymorphisms, which were calculated from the genotypic data of 858, 816, and 1676 chicken for P1, P2, and P1 + P2, respectively. Block colors indicate the LD status of SNPs; deep red means high linkages between two SNPs. The haplotypes block was defined by using the default setting of the Haploview software.

\section{Discussion}

Egg-laying rates are an important economic trait. With the extension of the laying cycle, the drop in egg-laying rates during the late laying period, has provoked great concern [2]. The present research was designed to uncover the critical SNPs in the RAPGEF6 gene that affect the egg-laying rate using egg production data from Jing Hong chickens with laying ages of 61 to 69 weeks. This study is the first to conduct a GWAS of egg-laying rates at the late laying period with the chicken $600 \mathrm{~K}$ high-density SNP array. Two populations of Jing Hong layer chickens were employed in this study to verify the GWAS results. Egg-laying performance is one of the most important economic traits in the poultry industry which is a crucial goal of breeding programs and has been attracting increasing interest. However, most of the egg production traits in chickens are inherited polygenically with low to moderate heritability [47-49]. Moreover, they are obtained only from sexually mature females, which makes genetic improvements in males more difficult to estimate using traditional methods depending on breeding value assessment. Innovatively improving and utilizing the egg production trait is becoming one of the essential tasks in the chicken industry. We tried to elucidate the relationships between polymorphisms of the RAPGEF6 gene and egg production traits to identify potential candidate molecular genetic markers as an aid in the improvement of egg production through marker-assisted selection and breeding in chicken. Nevertheless, since egg production traits are polygenically 
inherited, more associated target genes and favorable alleles are required for the improvement of egg production performance. Therefore, the polymorphisms in the RAPGEF6 gene were detected by the GWAS, screened using the PCR-RFLP method, and used to study genetic associations with egg production traits.

The genetic factors are destined to play a pivotal role in promoting egg production traits to further improve this economically important resource. In addition to a large number of the members of the hypothalamic-pituitary-gonadal hormone (HPG) axis, a wide variety of local intra-ovarian factors have been shown to play a critical role in normal follicular development and oocyte maturation, including the RAPGEF6 gene [31,50-54]. Involved in the process of egg production are not only members of the glycoprotein hormone family of gonadotropins, such as follicle-stimulating hormone (FSH) and luteinizing hormone (LH), but also a wide variety of local intra-ovarian cellular and tissue-level signal transductions that play a critical role in regulating normal follicular development and oocyte maturation [11,12,21]. These processes are also controlled by many local intra-ovarian factors in an autocrine or/and paracrine manner, such as the $\alpha 1 B$ ADR and PGC-1 $\beta$ proteins $[51,55,56]$. Polymorphisms associated with egg production related hormones, growth factors, and sex hormones such as follicle-stimulating hormone beta subunit $(\mathrm{FSHb}), \mathrm{LH}$, prolactin (PRL), growth hormone (GH), growth hormone receptor (GHR), transcription factor forkhead box L2 (FOXL2) and members of the transforming growth factor beta (TGF $\beta$ ) superfamily, including growth differentiation factor-9 (GDF9), have been intensively studied in chickens [5,20,56-59]. However, there is no information regarding polymorphisms in the chicken RAPGEF6 gene. To identify novel DNA markers associated with egg production traits in chickens, we examined polymorphisms in RAPGEF6 and evaluated their associations with egg production traits in Chinese Jing Hong laying hens.

RAPGEF6 is a protein-coding gene located on chromosome 13 in chickens, which shows an important role in the reproduction. Previous findings demonstrated that this gene is involved in the directing many vital processes including spermatogenesis [31,32]. This gene also engaged in maintaining a widespread cellular function linked to cellular responses, including cell adhesion, testicular atrophy, substantial decline in sperm quality and dramatic change exhibits in lowering fertility [31,32]. Moreover, RAPGEF6 gene in mice was demonstrated to be essential for male and/or female fertility. Results of current study showed that the egg-laying rate is significantly associated with three SNPs AX-75745366 (T15836649C), AX-75745340 (A15829057G) and AX-75745341 (A15829303G) which are found in RAPGEF6 gene. Furthermore, four haplotypes (AAGG, AAAG, AGGG and AGAG) were detected and the association analysis of haplotypes showed that the polymorphisms of SNP AX-75745340 (A15829057G) and AX-75745341 (A15829303G) in RAPGEF6 gene are significantly associated with egg production traits in Chinese Jing Hong layer chickens. Therefore, these results also strongly support that the three currently identified SNPs that are significantly associated in the RAPGEF6 gene might serve as a possible potential candidate in molecular genetic markers to aid in the improvement of egg production traits to be used in the breeding technique of chicken. The chi-square test results demonstrated that allelic and genotypic frequencies for the SNPs in the RAPGEF6 gene were not in Hardy-Weinberg equilibrium (HWE). These results suggest that the allelic and genotypic frequencies of the five polymorphic sites in the RAPGEF6 gene of the Chinese Jing Hong layer chicken population do not remain constant from generation to generation due to the influence of selection, mate choice, migration, and mutation. SNPs were tested and demonstrated a remarkably genetic disequilibrium between alleles, which might change the population structure and genetic drift in the studied populations.

Furthermore, we demonstrated that for SNP-01, AX-75745366 (T15836649C), the frequency of allele $\mathrm{T}$ was predominantly higher than allele $\mathrm{C}$ and frequency of genotype $\mathrm{TT}$, and $\mathrm{TC}$ was higher than that of genotype CC in the Jing Hong layer chicken of P1, P2, and P1 + P2 populations, but only after the whole population was found to exhibit a significant genetic disequilibrium between $\mathrm{T}$ and $\mathrm{C}$ alleles in RAPGEF6 $(p<0.05)$. This shows a low genetic diversity in the population, which may mainly be due to the cause of selection. Moreover, gene homozygosity $(\mathrm{Ho})$ was higher than 
gene heterozygosity ( $\mathrm{He}$ ) for the SNP-01, AX-75745366 (T15836649C), which was also found to be under genetic disequilibrium. The reason why this phenomenon occurring may be explained mainly by the following two aspects: (i) the mutation of allele $\mathrm{T}$ to allele $\mathrm{C}$ in this RAPGEF6 fragment was initially present in the original chicken population at a lower frequency; (ii) this substitution has occurred recently. Even if the allele $\mathrm{T}$ was correlated with the significantly higher egg production traits, a breeding purpose to enhance body weight and egg weight traits resulted in the presentation of the allele $C$, and the selection pressure was not enough to increase the frequency of allele $C$ up to a higher level within a very limited number of generations. If this reason were true, the genetic disequilibrium is easily understood, as mentioned above.

For SNP-03, AX-75745340 (A15829057G), the frequency of allele A is higher than allele G, and the frequency of genotype AA was higher than that of genotype AG in the Jing Hong layer chicken of P1, $\mathrm{P} 2$, and in $\mathrm{P} 1+\mathrm{P} 2$ populations. Although the $\mathrm{P} 1$ population showed significant genetic equilibrium $(p>0.05)$, the $\mathrm{P} 2$ population did not show genetic equilibrium $(p<0.05)$, and the P1 + P2 population was found to exhibit significant genetic disequilibrium between A and G alleles in RAPGEF6 $(p<0.05)$. This shows a low genetic diversity in the population, which may be mainly due to the cause of selection. Additionally, gene homozygosity $(\mathrm{Ho})$ was higher than heterozygosity $\mathrm{He}$ ) for the SNP-03: AX-75745340 (A15829057G) was shown to be under genetic disequilibrium. The main reason for this phenomenon may be a tight linkage of the allele A with either an advantageous allele or with an artificially selected and therefore economically desirable trait, such as higher egg production. Egg production traits of Chinese local Jing Hong populations have already been improved to enhance early sexual maturity, egg-laying numbers, and egg weight traits in the last decades. Another reason may be attributed to allele $\mathrm{A}$ being naturally one of the dominant alleles during genetic evolution, thus being more conserved and more common than other alleles in this population. It certainly cannot be ignored that the number of birds examined in this population was not enough to demonstrate the true event, and an extreme allele frequency was estimated as a result.

For SNP-05, AX-75745341 (A15829303G), the frequency of allele G was higher than allele A and the frequency of genotype GG was higher than that of genotype AG in the Jing Hong layer chicken of $\mathrm{P} 1, \mathrm{P} 2$, and $\mathrm{P} 1+\mathrm{P} 2$ populations. Although the P1 population showed genetic equilibrium $(p>0.05)$, the $\mathrm{P} 2$ population did not show genetic equilibrium $(p<0.05)$, and the $\mathrm{P} 1+\mathrm{P} 2$ population was found to exhibit significant genetic disequilibrium between $\mathrm{A}$ and $\mathrm{G}$ alleles in RAPGEF6 $(p<0.05)$. This shows a low genetic diversity in the population, which may be mainly due to the cause of selection. Moreover, gene homozygosity $(\mathrm{Ho})$ was higher than gene heterozygosity $(\mathrm{He})$ for the SNP-05, AX-75745341 (A15829303G). This SNP was found to be under genetic disequilibrium, possibly due to allele $\mathrm{G}$ in RAPGEF6 being naturally one of the predominant alleles during genetic evolution and thus being more conserved and more common than other alleles in this population. Furthermore, it is possible that allele A or G may be tightly linked with either an advantageous allele or with an artificially selected economically favorable trait, such as higher egg production and egg weight. Hence, the homozygotes with genotype AA or GG were either promoted under natural selection pressures to be better adapted, or they were artificially selected for favorable agricultural attributes. In fact, the egg production traits of Chinese local Jing Hong populations have already been improved with the aim to enhance early sexual maturity, egg-laying numbers, and egg weight traits for the past six generations. In this local Chinese Jing Hong chicken breeding, the A or G alleles may be coincidently linked with one or more of the selected breeding traits, thus presenting a possible explanation for higher allelic frequencies. Additionally, it cannot be ignored that the number of birds examined in each population was not enough to demonstrate the true event, and an extreme allele frequency was estimated as a result.

The results of the association study and the linkage disequilibrium (LD) analysis revealed that the three significantly associated SNPs were closely linked together in this region. Linkage disequilibrium (LD) plays a vital role in mapping genes that affect complex diseases and identifying association among genetic markers and functional genes [60]. Understanding LD among SNP also avoids redundant inferences involving non-independent genetic markers. The result of this study indicates 
that three variants in RAPGEF6 gene are in significant LD with each other. In the P1 population, two variants, AX-75745341A/G and AX-75745341A/G, showed non-significant LD with each other with low $\mathrm{D}^{\prime}\left(\mathrm{D}^{\prime}=13\right)$ and spanning $0 \mathrm{~kb}$ in block 1 only. In the case of the P2 population, three variants, AX-75745340A/G, AX-75745341A/G, and AX-75745366T/C, showed significant LD with each other with highly strong $\mathrm{D}^{\prime}\left(\mathrm{D}^{\prime}=93\right.$ and 83 ) and spanning $7 \mathrm{~kb}$ in block 1 only. Finally, in the case of the whole P1 + P2 population, two variants, AX-75745340A/G and AX-75735341/G, showed significant LD with each other with strong $D^{\prime}\left(D^{\prime}=69\right)$ and spanning $0 \mathrm{~kb}$ in block 1 only. The LD analysis revealed that three variants, AX-75745340A/G, AX-75745341A/G, and AX-75745366T/C, in the RAPGEF6 gene were significantly associated with the egg-laying rate.

Collectively, the results of the present study strongly suggest that the three novel SNPs are associated with the egg-laying rate and are thus potential molecular markers for egg productivity in local Chinese Jing Hong chicken breeding.

\section{Conclusions}

In conclusion, five SNPs that are associated with egg-laying rate were selected by the GWAS in a parent population. Out of them, three SNPs were confirmed in two commercial populations with PCR-RFLP genotyping data and egg-laying rates. Based on the results of an association analysis, it has been shown that the T allele at SNP AX-75745366 (t15846449T>C), the A allele at SNP AX-75745340 $($ a15829057A $>G)$, and the G allele at SNP AX-75745341 (g15829303A $>$ G) in the RAPGEF6 gene are the most potential candidate molecular genetic markers that can be used to improve the egg production traits in MAS programs. Furthermore, the RAPGEF6 gene is not only beneficial in males but can also be considered as one of the novel potential candidate gene in regulating egg production traits in females. Our present study therefore brings new insight on the RAPGEF6 gene function in Chinese Jing Hong chickens. This study not only provides the candidate genetic markers for a marker-assisted selection of Chinese Jing Hong hens, but also provides a basic knowledge for further studies on SNP detection on the RAPGEF6 genes in other chicken breeds and other animal species.

\section{Patent}

Patent applying No: 201810428916.5 resulting from the work.

Supplementary Materials: The supplementary materials are available online at http://www.mdpi.com/2073-4425/ 10/5/384/s1, Figure S1: The electrophoretic result of PCR-RFLP band patterns of RAPGEF6 gene at 15836649 bp in chicken. DNA was digested with the restriction enzyme MnlI and three types of genotypes (TT, TC and CC) are shown at the top (M: DL600 plus); Figure S2: The electrophoretic result of PCR-RFLP band patterns of RAPGEF6 gene at $15843452 \mathrm{bp}$ in chicken. DNA was digested with the restriction enzyme MboI and two types of genotypes (CC and CT) are shown at the top (M: DL600 plus); Figure S3: The electrophoretic result of PCR-RFLP band patterns of RAPGEF6 gene at $15829057 \mathrm{bp}$ in chicken. DNA was digested with the restriction enzyme XmnI and two types of genotypes (AA and AG) are shown at the top (M: DL600 plus). Figure S4: The electrophoretic result of PCR-RFLP band patterns of RAPGEF6 gene at 15845449 bp in chicken. DNA was digested with the restriction enzyme MwoI and two types of genotypes (GG and GA) are shown at the top (M: DL600 plus); Figure S5: The electrophoretic result of PCR-RFLP band patterns of RAPGEF6 gene at $15829303 \mathrm{bp}$ in chicken. DNA was digested with the restriction enzyme HphI and two types of genotypes (AG and GG) are shown at the top (M: DL600 plus); Table S1: Information of five variants (SNPs) in RAPGEP6 gene in Chicken; Table S2: Primer information for the fragments of SNPs in chicken RAPGEF6 gene amplified; Table S3: The ingredients of RAPGEF6 PCR-RFLP optimized Restriction Enzyme $(R E)$ digestion mixture; Table S4: The restriction enzymes with their recognition site/cut position used to digest the PCR products.

Author Contributions: This work was carried out in collaboration with all authors. Conceptualization, S.A.A., S.Z., and L.S.; Data curation, S.A.A., S.M., C.S., Z.H., and M.Z.; Formal analysis, S.A.A., A.A.B., A.I.O., and S.M.; Funding acquisition, S.Z and L.S.; Investigation, S.A.A., S.Z, and L.S.; Methodology, S.A.A., A.A.B., and A.I.O.; Project administration, S.A.A., S.Z., and L.S.; Resources, C.S., Z.H., M.Z., S.Z., and L.S.; Software, S.A.A., A.I.O., and S.M.; Supervision, S.Z. and L.S.; Validation, S.A.A., S.Z., and L.S.; Visualization, S.A.A., C.S., Z.H., and M.Z.; Writing-original draft, S.A.A; Writing-review \& editing, A.A.B., S.Z., and L.S.

Funding: This study was supported by the National Natural Science Foundation of China (Grant No. 31772585, 2018skjcx05, the Fundamental Research Funds for the Central Universities (No. 2662018PY088), Breeding and Reproduction in The Plateau Mountainous Region, Ministry of Education (No. GYSD-K-2018-01), Key R \& D 
and transformation plan of Tibet Autonomous Region (Grant No. CGZH2017000237), as well as the national key training project (2014GKXM057).

Acknowledgments: The authors confirm that the funders had no influence over the study design, content of the article, or selection of this journal. We are thankful to our colleagues Anjuman Ara Bhuyan, Mohammad Ishaque Ali, Mahmuda Bilkis Binte Alam, Mohammad Abdul Latif, Abdelmotaleb Elokil, Adeyinka Abiola Adetula, Huang Tao, and all members of the Poultry Molecular Genetics laboratory who provided expertise that greatly assisted the research, although any errors are our own and should not tarnish the reputations of these esteemed professionals.

Conflicts of Interest: The authors declare no conflict of interest.

\section{References}

1. Liu, Z.; Sun, C.; Yan, Y.; Li, G.; Shi, F.; Wu, G.; Liu, A.; Yang, N. Genetic variations for egg quality of chickens at late laying period revealed by genome-wide association study. Sci. Rep. 2018, 8, 10832. [CrossRef]

2. Schulte-Drüggelte, R.; Thiele, H.H. Determining the optimum replacement schedule for commercial layers: does molting pay off? Lohmann Inf. 2013, 48, 47.

3. Bain, M.M.; Nys, Y.; Dunn, I.C. Increasing persistency in lay and stabilising egg quality in longer laying cycles. What are the challenges? Br. Poult. Sci. 2016, 57, 330-338. [CrossRef]

4. Kim, M.H.; Seo, D.S.; Ko, Y. Relationship between egg productivity and insulin-like growth factor-I genotypes in Korean native Ogol chickens. Poultr. Sci. 2004, 83, 1203-1208. [CrossRef] [PubMed]

5. Qin, N.; Liu, Q.; Zhang, Y.Y.; Fan, X.C.; Xu, X.X.; Lv, Z.C.; Wei, M.L.; Jing, Y.; Mu, F.; Xu, R.F. Association of novel polymorphisms of forkhead box $\mathrm{L} 2$ and growth differentiation factor-9 genes with egg production traits in local Chinese Dagu hens. Poult. Sci. 2015, 94, 88-95. [CrossRef]

6. Jing, Y.; Shan, X.; Mu, F.; Qin, N.; Zhu, H.; Liu, D.; Yuan, S.; Xu, R. Associations of the Novel Polymorphisms of Periostin and Platelet-Derived Growth Factor Receptor-Like Genes with Egg Production Traits in Local Chinese Dagu Hens. Anim. Biotechnol. 2016, 27, s208-s216. [CrossRef] [PubMed]

7. Fairfull, R.W.; Gowe, R.S. Genetics of egg production in chickens. In Developments in Animal and Veterinary Sciences; Crawford, R.D., Ed.; Elsevier Science Publishers: Amsterdam, The Nederlands, 1990.

8. Wolc, A.; Arango, J.; Settar, P.; O'Sullivan, N.P.; Dekkers, J.C.M. Evaluation of egg production in layers using random regression models. Poult. Sci. 2011, 90, 30. [CrossRef] [PubMed]

9. Tyasi, T.L.; Qin, N.; Liu, D.; Niu, X.; Zhu, H.; Xu, R. The association between novel polymorphisms of gremlin genes and egg-laying performance traits in Chinese village Dagu hens. Ann. Anim. Sci. 2017, 18, 361-373. [CrossRef]

10. Liu, D.; Niu, X.L.; Tyasi, T.L.; Qin, N.; Zhu, H.; Chen, X.; Xu, R. New polymorphisms of PAPPA and PAPPA2 genes and their associations with egg production traits in Chinese Dagu chickens. Indian J. Anim. Res. 2017, 1-6. [CrossRef]

11. Mu, F.; Jing, Y.; Qin, N.; Zhu, H.Y.; Liu, D.H.; Yuan, S.G.; Xu, R.F. Novel Polymorphisms of Adrenergic, Alpha-1B-, Receptor and Peroxisome Proliferator-activated Receptor Gamma, Coactivator 1 Beta Genes and Their Association with Egg Production Traits in Local Chinese Dagu Hens. Asian-Australas. J. Anim. Sci. 2016, 29, 1256-1264. [CrossRef] [PubMed]

12. Niu, X.; Tyasi, T.L.; Qin, N.; Liu, D.; Zhu, H.; Chen, X.; Zhang, F.; Yuan, S.; Xu, R. Sequence variations in estrogen receptor 1 and 2 genes and their association with egg production traits in Chinese Dagu chickens. J. Vet. Med. Sci. 2017, 79, 927-934. [CrossRef] [PubMed]

13. Charoensook, R.; Wichasit, N.; Pechrkong, T.; Incharoen, T.; Numthuam, S. STAT5B Gene Polymorphisms are Associated with Egg Production and Egg Quality Traits in Laying Hens. Asian J. Anim. Vet. Adv. 2016, 11, 847-853. [CrossRef]

14. Hu, Y.D.; Huang, Q.K.; Zhu, Q.; Lan, D.; Feng, Z.Q.; Zhang, L.; Lan, X.; Ye, L.; Liu, Y.P.; He, M. Identification and association of single-nucleotide polymorphisms in gonadotropin-inhibitory hormone $(\mathrm{GnIH})$ gene with egg production traits in Erlang mountainous chickens. Genet. Mol. Res. 2015, 14, 294-303. [CrossRef]

15. Zhang, N.B.; Tang, H.; Kang, L.; Ma, Y.H.; Cao, D.G.; Lu, Y.; Hou, M.; Jiang, Y.L. Associations of single nucleotide polymorphisms in BMPR-IB gene with egg production in a synthetic broiler line. Asian-Australas. J. Anim. Sci. 2008, 21, 628-632. [CrossRef] 
16. Wang, Y.; Xiao, L.H.; Zhao, X.L.; Liu, Y.P.; Zhu, Q. Identification of SNPs in Cellular Retinol Binding Protein 1 and Cellular Retinol Binding Protein 3 Genes and Their Associations with Laying Performance Traits in Erlang Mountainous Chicken. Asian-Australas. J. Anim. Sci. 2014, 27, 1075-1081. [CrossRef] [PubMed]

17. Wang, Z.P.; Meng, G.H.; Li, N.; Yu, M.F.; Liang, X.W.; Min, Y.N.; Liu, F.Z.; Gao, Y.P. The association of very low-density lipoprotein receptor (VLDLR) haplotypes with egg production indicates VLDLR is a candidate gene for modulating egg production. Genet. Mol. Biol. 2016, 39, 380-391. [CrossRef] [PubMed]

18. Li, D.Y.; Zhang, L.; Smith, D.G.; Xu, H.L.; Liu, Y.P.; Zhao, X.L.; Wang, Y.; Zhu, Q. Genetic effects of melatonin receptor genes on chicken reproductive traits. Czech J. Anim. Sci. 2013, 58, 58-64. [CrossRef]

19. Xu, H.; Xu, S.; Min, Z.; Fang, M.; Hua, Z.; Nie, Q.; Zhang, X. The genetic effects of the dopamine D1 receptor gene on chicken egg production and broodiness traits. BMC Genet. 2010, 11, 17. [CrossRef]

20. Cui, J.X.; Du, H.L.; Liang, Y.; Deng, X.M.; Li, N.; Zhang, X.Q. Association of polymorphisms in the promoter region of chicken prolactin with egg production. Poult. Sci. 2006, 85, 26-31. [CrossRef]

21. Qin, N.; Fan, X.C.; Zhang, Y.Y.; Xu, X.X.; Tyasi, T.L.; Jing, Y.; Mu, F.; Wei, M.L.; Xu, R.F. New insights into implication of the SLIT/ROBO pathway in the prehierarchical follicle development of hen ovary. Poult. Sci. 2015, 94, 2235-2246. [CrossRef]

22. Wilkanowska, A.; Mazurowski, A.; Mroczkowski, S.; Kokoszyński, D. Prolactin (PRL) and prolactin receptor (PRLR) genes and their role in poultry production traits. Folia Biol. 2014, 62, 1-8. [CrossRef]

23. Jin, C.F.; Chen, Y.J.; Yang, Z.Q.; Shi, K.; Chen, C.K. A genome-wide association study of growth trait-related single nucleotide polymorphisms in Chinese Yancheng chickens. Gen. Mol. Res. 2015, 14, 15783-15792. [CrossRef]

24. Ross, S.H.; Post, A.; Raaijmakers, J.H.; Verlaan, I.; Gloerich, M.; Bos, J.L. Ezrin is required for efficient Rap1-induced cell spreading. J. Cell Sci. 2011, 124, 1808-1818. [CrossRef] [PubMed]

25. Post, A.; Pannekoek, W.J.; Ross, S.H.; Verlaan, I.; Brouwer, P.M.; Bos, J.L. Rasip1 mediates Rap1 regulation of Rho in endothelial barrier function through ArhGAP29. Proc. Natl. Acad. Sci. USA 2013, 110, 11427-11432. [CrossRef] [PubMed]

26. Pannekoek, W.J.; van Dijk, J.J.; Chan, O.Y.; Huveneers, S.; Linnemann, J.R.; Spanjaard, E.; Brouwer, P.M.; van der Meer, A.J.; Zwartkruis, F.J.; Rehmann, H.; et al. Epac1 and PDZ-GEF cooperate in Rap1 mediated endothelial junction control. Cell. Signal. 2011, 23, 2056-2064. [CrossRef]

27. Bos, J.L. Linking Rap to cell adhesion. Curr. Opin. Cell Biol. 2005, 17, 123-128. [CrossRef]

28. Duchniewicz, M.; Zemojtel, T.; Kolanczyk, M.; Grossmann, S.; Scheele, J.S.; Zwartkruis, F.J. Rap1A-deficient $\mathrm{T}$ and B cells show impaired integrin-mediated cell adhesion. Mol. Cell. Biol. 2006, 26, 643-653. [CrossRef]

29. Okada, K.; Chiba, K.; Fukuda, T.; Enatsu, N.; Matsushita, K.; Miyake, H.; Maeta, K.; Edamatsu, H.; Kataoka, T.; Fujisawa, M. Loss of RA-GEF-2 (RAPGEF6) in mouse causes altered localization of N-cadherin and can cause male infertility. J. Urol. 2014, 191, e741. [CrossRef]

30. Kazuhiro, M.; Hironori, E.; Kaori, N.; Junji, I.; Bilasy, S.E.; Tohru, K. Crucial Role of Rapgef2 and Rapgef6, a Family of Guanine Nucleotide Exchange Factors for Rap1 Small GTPase, in Formation of Apical Surface Adherens Junctions and Neural Progenitor Development in the Mouse Cerebral Cortex. eNeuro 2016, 3, ENEURO.0142-16.2016. [CrossRef]

31. Okada, K.; Miyake, H.; Yamaguchi, K.; Chiba, K.; Maeta, K.; Bilasy, S.E.; Edamatsu, H.; Kataoka, T.; Fujisawa, M. Critical function of RA-GEF-2/Rapgef6, a guanine nucleotide exchange factor for Rap1, in mouse spermatogenesis. Biochem. Biophys. Res. Commun. 2014, 445, 89-94. [CrossRef]

32. Okada, K.; Yamaguchi, K.; Enatsu, N.; Li, F.; Matsushita, K.; Chiba, K.; Miyake, H.; Maeta, K.; Bilasy, S.E.; Edamatsu, H.; et al. Critical function of RA-GEF-2 (RAPGEF6) in mouse spermatogenesis. J. Urol. 2013, 189, e833-e834. [CrossRef]

33. Levy, R.J.; Kvajo, M.; Li, Y.; Tsvetkov, E.; Dong, W.; Yoshikawa, Y.; Kataoka, T.; Bolshakov, V.Y.; Karayiorgou, M.; Gogos, J.A. Deletion of Rapgef6, a candidate schizophrenia susceptibility gene, disrupts amygdala function in mice. Transl. Psychiatry 2015, 5, e577. [CrossRef] [PubMed]

34. Levy, R.J. Exploring the Role of Rapgef6 in Neuropsychiatric Disorders. Ph.D. Thesis, Columbia University, New York, NY, USA, 2013.

35. Tamura, K.; Stecher, G.; Peterson, D.; Filipski, A.; Kumar, S. MEGA6: Molecular Evolutionary Genetics Analysis version 6.0. Mol. Biol. Evol. 2013, 30, 2725-2729. [CrossRef]

36. Sambrook, J.; Russell, D.W. Purification of nucleic acids by extraction with phenol: Chloroform. CSH Protoc. 2006, 2006. [CrossRef] [PubMed] 
37. Kranis, A.; Gheyas, A.A.; Boschiero, C.; Turner, F.; Yu, L.; Smith, S.; Talbot, R.; Pirani, A.; Brew, F.; Kaiser, P.; et al. Development of a high density 600K SNP genotyping array for chicken. BMC Genom. 2013, 14, 59. [CrossRef] [PubMed]

38. Wang, D.; Sun, Y.; Stang, P.; Berlin, J.A.; Wilcox, M.A.; Li, Q. Comparison of methods for correcting population stratification in a genome-wide association study of rheumatoid arthritis: principal-component analysis versus multidimensional scaling. BMC Proc. 2009, 3, S109. [CrossRef] [PubMed]

39. Zhang, Z.; Ersoz, E.; Lai, C.-Q.; Todhunter, R.J.; Tiwari, H.K.; Gore, M.A.; Bradbury, P.J.; Yu, J.; Arnett, D.K.; Ordovas, J.M.; et al. Mixed linear model approach adapted for genome-wide association studies. Nat. Genet. 2010, 42, 355-360. [CrossRef] [PubMed]

40. Bradbury, P.J.; Zhang, Z.; Kroon, D.E.; Casstevens, T.M.; Ramdoss, Y.; Buckler, E.S. TASSEL: software for association mapping of complex traits in diverse samples. Bioinformatics 2007, 23, 2633-2635. [CrossRef] [PubMed]

41. Duggal, P.; Gillanders, E.M.; Holmes, T.N.; Bailey-Wilson, J.E. Establishing an adjusted p-value threshold to control the family-wide type 1 error in genome wide association studies. BMC Genom. 2008, 9, 516. [CrossRef]

42. Stephens, M.; Smith, N.J.; Donnelly, P. A new statistical method for haplotype reconstruction from population data. Am. J. Hum. Genet. 2001, 68, 978-989. [CrossRef]

43. Barrett, J.C.; Fry, B.; Maller, J.; Daly, M.J. Haploview: analysis and visualization of LD and haplotype maps. Bioinformatics 2005, 21, 263-265. [CrossRef]

44. Yeh, F.C.; Yang, R.-C.; Boyle, T.B.J.; Ye, Z.H.; Mao, J.X. POPGENE, the user-friendly shareware for population genetic analysis. In Molecular Biology and Biotechnology Centre; University of Alberta: Edmonton, AB, Canada, 1997.

45. SAS. Sas/Ets 9.2 User's Guide; SAS Publishing: Cary, NC, USA, 2009.

46. Duncan, D.B. Multiple Range and Multiple F Tests. Biometrics 1955, 11, 1-42. [CrossRef]

47. Luo, P.T.; Yang, R.Q.; Yang, N. Estimation of Genetic Parameters for Cumulative Egg Numbers in a Broiler Dam Line by Using a Random Regression Model. Poult. Sci. 2007, 86, 30-36. [CrossRef]

48. Biscarini, F.; Bovenhuis, H.; Ellen, E.D.; Addo, S.; van Arendonk, J.A. Estimation of heritability and breeding values for early egg production in laying hens from pooled data. Poult. Sci. 2010, 89, 1842-1849. [CrossRef]

49. Venturini, G.C.; Savegnago, R.P.; Nunes, B.N.; Ledur, M.C.; Schmidt, G.S.; El, F.L.; Munari, D.P. Genetic parameters and principal component analysis for egg production from White Leghorn hens. Poult. Sci. 2013, 92, 2283-2289. [CrossRef] [PubMed]

50. Schmahl, J.; Rizzolo, K.; Soriano, P. The PDGF signaling pathway controls multiple steroid-producing lineages. Genes Dev. 2008, 22, 3255-3267. [CrossRef] [PubMed]

51. McDerment, N.A.; Wilson, P.W.; Waddington, D.; Dunn, I.C.; Hocking, P.M. Identification of novel candidate genes for follicle selection in the broiler breeder ovary. BMC Genom. 2012, 13, 494. [CrossRef]

52. Ismail, R.S.; Baldwin, R.L.; Fang, J.; Browning, D.; Karlan, B.Y.; Gasson, J.C.; Chang, D.D. Differential Gene Expression between Normal and Tumor-derived Ovarian Epithelial Cells. Cancer Res. 2000, 60, 6744-6749. [PubMed]

53. Syed, V.; Zhang, X.K.; Lau, K.M.; Cheng, R.; Mukherjee, K.; Ho, S.M. Profiling estrogen-regulated gene expression changes in normal and malignant human ovarian surface epithelial cells. Oncogene 2005, 24, 8128-8143. [CrossRef] [PubMed]

54. Soriano, P. Abnormal kidney development and hematological disorders in PDGF beta-receptor mutant mice. Genes Dev. 1994, 8, 1888-1896. [CrossRef]

55. Aguado, L.I.; Ojeda, S.R. Prepubertal rat ovary: hormonal modulation of beta-adrenergic receptors and of progesterone response to adrenergic stimulation. Biol. Reprod. 1986, 34, 45-50. [CrossRef] [PubMed]

56. Tcherepanova, I.; Puigserver, P.; Norris, J.D.; Spiegelman, B.M.; Mcdonnell, D.P. Modulation of estrogen receptor-alpha transcriptional activity by the coactivator PGC-1. J. Biol. Chem. 2000, 275, 16302-16308. [CrossRef] [PubMed]

57. Onagbesan, O.M.; Metayer, S.; Tona, K.; Williams, J.; Decuypere, E.; Bruggeman, V. Effects of genotype and feed allowance on plasma luteinizing hormones, follicle-stimulating hormones, progesterone, estradiol levels, follicle differentiation, and egg production rates of broiler breeder hens. Poult. Sci. 2006, 85, 1245-1258. [CrossRef] 
58. Kim, D.; Ocón-Grove, O.; Johnson, A.L. Bone morphogenetic protein 4 supports the initial differentiation of hen (Gallus gallus) granulosa cells. Biol. Reprod. 2013, 88, 161. [CrossRef] [PubMed]

59. Nonis, D.; Mctavish, K.J.; Shimasaki, S. Essential but differential role of FOXL2 wt and FOXL2 C134W in GDF-9 stimulation of follistatin transcription in co-operation with Smad3 in the human granulosa cell line COV434. Mol. Cell. Endocrinol. 2013, 372, 42-48. [CrossRef]

60. Hazelett, D.J.; Conti, D.V.; Han, Y.; Al Olama, A.A.; Easton, D.; Eeles, R.A.; Kote-Jarai, Z.; Haiman, C.A.; Coetzee, G.A. Reducing GWAS Complexity. Cell Cycle 2016, 15, 22-24. [CrossRef] [PubMed]

(C) 2019 by the authors. Licensee MDPI, Basel, Switzerland. This article is an open access article distributed under the terms and conditions of the Creative Commons Attribution (CC BY) license (http://creativecommons.org/licenses/by/4.0/). 